\title{
Linguce é
}

\section{Rivista di lingue e culture moderne}

$\begin{array}{ll}\text { Nota sugli Autori } & 7\end{array}$

Roberta Mullini $\quad 11$

Editoriale

Fabio Ciambella

Danza, lingua e potere: (s)cortesia ne La dodicesima notte di Shakespeare

Daniela Francesca Virdis

"Lay down branch roads, provide town sites, build barracks":

A Practical Stylistic Investigation of Hyde Clarke's Colonization, Defence, and Railways in Our Indian Empire (1857)

Alessandra Calanchi

Quando manca il detective. La presa in carico dell'investigazione in due racconti americani di fine Ottocento

(When the Detective is Missing: Taking Charge of the Investigation in Two Late Nineteenth-Century American Short Stories)

Beatrice Nori

Dreadful Dolls: Female Power in Carol Ann Duffy 
Lo jurodivyj in Nostalghia. Genesi ed evoluzione di Domenico nella sceneggiatura di Tarkovskij e Guerra

(The jurodivyj in Nostalghia: The Character of Domenico in Andrej Tarkovskij and Tonino Guerra's Script Writing)

Alessandra Pettinelli, Chiara Sola, Monique Carbone Cintra,

Luca Avellini

E-learning e futuri studenti in mobilità internazionale. Riflessioni

su aspetti e potenzialità di un corso di lingua italiana

(E-Learning and Future Students in International Mobility:

Considerations about Aspects and Makings of an Italian Language

Course)

Cecilia Lazzeretti

Communicating Sustainable Tourism in English and Italian:

A Contrastive Analysis

Cristina Solimando

Linguistic Interference and Religious Identity: The Case

of a Lebanese Speech Community

RECENSIONI 


\title{
"Lay down branch roads, provide town sites, build barracks": A Practical Stylistic Investigation of Hyde Clarke's Colonization, Defence, and Railways in Our Indian Empire (1857)
}

\author{
Daniela Francesca Virdis
}

dfvirdis@unica.it

Università degli Studi di Cagliari

DOI: https://doi.org/10.7358/ling-2020-002-vird

\begin{abstract}
In his treatise Colonization, Defence, and Railways in Our Indian Empire (1857), Hyde Clarke wholeheartedly approves of Indian colonial railways and advocates the need for the British to bring about technological progress in the subcontinent. The main research purpose of this article is to provide stylistic evidence of how Clarke relays and constructs his Anglocentric and imperial viewpoint on Indian railways. The article firstly introduces the figure of Clarke and his railway pamphlet, and discusses the keywords colonialism and colonization as defined in two authoritative nineteenthcentury dictionaries of the English language and in colonial and postcolonial studies. Secondly, moving from this field and from the field of postcolonial stylistics, the stylistic methodology defined by Ron Carter as "practical stylistics" is applied to thirteen sequences from the treatise including the keyword colonization. Finally, the definitions of colonialism and colonization are compared with Clarke's notion of colonization as emerging from the text. This linguistic analysis hence identifies and explores the stylistic strategies utilised by the author - mainly stylistic choices at word- and phrase-level, syntactic structures and the pragmatic functions of these devices - and reveals the ways in which he conveys his colonial mental attitude to the Indian reality.
\end{abstract}

KEYWORDS - Hyde Clarke; Colonization, Defence, and Railways in Our Indian Empire; practical stylistics; Indian railways; colonialism; colonization; Victorian nonfictional prose.

\section{INTRODUCTION: BRITISH RAILWAYS IN COLONIAL INDIA}

The pre-Indian Mutiny subcontinent was a country still dependent in most part on slow, unreliable, expensive transportation through monsoon-fed rivers and bullock carts. The sensational development of India's colonial rail- 
ways, with their unmatched rapid spread and complex network, is one of those contentious topics allowing various interpretations from diverse ideological stances. The first 21-mile stretch of Indian railway line, from Bombay to Thane, was inaugurated in 1853 ; the operating route miles totalled 838 in 1860, immediately after the 1857 Indian Mutiny (see below). In 1900 colonial railways in India, with their 23,627 mile route, were Asia's largest network, the world's fourth largest, the world's fifth largest in passenger travel and the world's sixth largest in freight (Kerr 2001, 1; Misa 2004, 113). In a word, "the railways of colonial India dwarfed those in any other 19th-century colonial or semi-colonial setting" (Kerr 2001, 1), be it that in Asia, Africa or Latin America.

In an article about John Masters's railway novel Bhowani Junction (1951), Johnson $(2000,12)$ briefly cites and compares two authoritative voices in the history of Indian colonial railways, namely those of George Otto Trevelyan and Jawaharlal Nehru. They reflect the thoughts about the railway system in the subcontinent of those historical players whom Iqbal $(2006,173)$ distinguishes as "two categories of people: those who had a romantic vision of India, often diluted by ingredients of 'civilizing mission' and those who found India as a veritable home for capitalist initiatives". Sir George Otto Trevelyan, 2nd Baronet (1838-1928), was a British politician who, in 1862, went out as a civil servant to India, where he spent several years. During his stay, he contributed a series of fictionalised letters home to Macmillan's Magazine, which were also published in a single volume under the title of Letters of a Competition Wallah (1864). An empire usually leaves its imprint in the infrastructure which it constructs, and it directly or indirectly reveals the imperial value system; Indian colonial railways hence provide a prime case study. British engineers actually planned the design and the technical details of bridges, locomotives and particularly terminals to be both state-of-the art and durable, and correspondingly impressive and expensive. Moreover, all this infrastructure was either entirely built in Britain, or its constituent parts were imported from there and then assembled in India (Srinivasan 2006, xxvxxvi). As a result, in "Letter II" (Trevelyan 1864, 21-46; partly reprinted in Trevelyan 1998, 3-8), the fictional author of the text describes a train journey in Bengal and comments enthusiastically and romantically on the British railway infrastructure and facilities ${ }^{1}$ :

${ }^{1}$ For an ecostylistic analysis of Trevelyan's text, see Virdis 2012. Although they concern the literature of what he calls "the Era of Confidence" (1880-1910), Greenberger's 
Never was I so impressed with the triumphs of progress, the march of mind. In fact, all the usual common-places genuinely filled my soul. Those two thin strips of iron, representing as they do the mightiest and the most fruitful conquest of science, stretch hundreds and hundreds of miles across the boundless Eastern plains [...]. Keep to the line, and you see everywhere the unmistakable signs of England's handiwork. There are the colossal viaducts, spanning wide tracts of pool and sandbank, which the first rains will convert into vast torrents. There are the long rows of iron sheds, with huge engines running in and out of them with that indefiniteness of purpose which seems to characterise locomotives all over the world. There is the true British stationmaster, grand but civil on ordinary occasions, but bursting into excitement and ferocity when things go wrong, or when his will is disputed; who fears nothing human or divine, except the daily press. There is the refreshment-room, with its half-crown dinner that practically always costs five and ninepence. Stroll a hundred yards from the embankment, and all symptoms of civilization have vanished. (Trevelyan 1864, 25-26)

The second author cited by Johnson $(2000,12)$ with reference to Indian colonial railways is Jawaharlal Nehru (1889-1964), one of the most prominent figures in the Indian independence movement and the country's first prime minister. In his Autobiograpby (1936), he discusses the British introduction of industrialism and scientific progress in India, and focuses on Indian colonial railways. Since "railway imperialism typically led toward political centralization, economic concentration, and extractive development" (Misa 2004, 113), Nehru perceptively identifies the train as one of the main technological tools by means of which the English exploited and dominated, i.e., colonised, the Indian subcontinent politically and economically ${ }^{2}$ :

Railways, telegraphs, telephones, wireless, and the like [...] were welcome and necessary, and, because the British happened to be the agents who brought them first, we should be grateful to them. But even these heralds of industrialism came to us primarily for the strengthening of British rule. They were the veins

$(1969,5)$ remarks also seem to fit Trevelyan's work and worldview as conveyed in "Letter II": "The Era of Confidence is dominated by writers who presented the image of a confident and secure empire. The authors of this period all shared a common faith in the value of British civilization. [...] Starting with this confident approach to their own civilization, these authors believed in their position as rulers and the complementary Indian position as subordinates".

${ }^{2}$ For an introduction to and a definition of colonialism and imperialism, see Loomba (1998) 2015, which is also discussed below; for the historical dynamics and the political impact of imperialism, see Smith 1981.

Linguce \& $-2 / 2020$

https://www.ledonline.it/linguae/ - Online ISSN 1724-8698 - Print ISSN 2281-8952 - ISBN 978-88-7916-961-5 
and arteries through which the nation's blood should have coursed, increasing its trade, carrying its produce, and bringing new life and wealth to its millions. It is true that in the long run some such result was likely, but they were designed and worked for another purpose - to strengthen the imperial hold and to capture markets for British goods - which they succeeded in achieving. I am all in favor of industrialization and the latest methods of transport, but sometimes, as I rushed across the Indian plains, the railway, that life-giver, has almost seemed to me like iron bands confining and imprisoning India. (Nehru 1982, 435)

In the treatise Colonization, Defence, and Railways in Our Indian Empire (1857) by Hyde Clarke (1815-1895), the reader can find a coherent interweaving of ideas close to the positions Trevelyan and Nehru will take seven and seventy-nine years later respectively. More precisely, this pamphlet features an ideological, wholehearted approval of Indian colonial railways and a strong conviction of their worthiness and effectiveness, similar to Trevelyan's. This approval is used to advocate and champion the need for the British to bring about technological progress in the subcontinent mostly to advance their own political, military and economic interests in the area, that is to say, the reality Nehru will sharply be aware of nearly eighty years later.

\section{RESEARCH PURPOSE, BACKGROUND AND METHODOLOGY}

As will be shown in the analytical Section 5 , in his treatise Clarke articulates a biased Anglocentric mindset or perspective and an imperial value system in which the colonisers bring innovation, modernity and wealth, and the colonised are inept, unreasonable and superstitious. My main research purpose in this article is to provide linguistic evidence of how Clarke's Anglocentric and imperial viewpoint on Indian colonial railways and the entire Indian subcontinent is relayed and constructed in his text. In other words, I distinguish and scrutinise the stylistic strategies this author utilises to convey his seemingly progressive ideology and his colonial mental attitude to the Indian reality.

Those put forward by Clarke are the classic arguments and assumptions critiqued by contemporary colonial and postcolonial studies and theory (to mention just a few, see Bhabha [1994] 2004; Ashcroft, Griffiths, and Tiffin [1995] 2006; Ashcroft, Griffiths, and Tiffin [2000] 2007; Fanon [1952] 2008; Young [2001] 2016). These literary and cultural studies have recently interacted with the linguistic discipline of stylistics (Leech and Short [1981] 2007; 
Burke 2014; Simpson [2004] 2014; Stockwell and Whiteley 2014; Sotirova 2015). As a result, the new field of research of postcolonial stylistics has emerged, whose aim is to employ the theoretical framework and methodology of stylistics to explore postcolonial literatures and postcolonial fictional texts produced by writers from countries once colonised by European powers (Tunca 2014; Zurru 2017; Adami 2018; Adami 2019; Tunca 2020). Moving from both these areas, my research in the present article explores a colonial text by applying a stylistic approach, rather than a literary or cultural approach; moreover, it adopts stylistics to examine a colonial non-fictional work by a coloniser, rather than a postcolonial fictional work by an author from a former colony. For these reasons, the article may make an analytical contribution to an undeveloped research area in colonial studies and stylistic studies alike.

The stylistic methodology adopted here to examine Clarke's Anglocentric worldview was defined by Carter $(2010,58-61)$ as "practical stylistics" or "steam stylistics". Practical stylistics is founded on the assumption that texts are made from language and with language, and is based on the analyst and their knowledge of the language. It entails close reading of the linguistic texture of the work under investigation and the systematic identification of the choices and patterns in it. The primary aims of this methodology are to show how linguistic choices give rise to interpretations and to explain the effects such linguistic choices produce. The major stylistic devices found in Clarke's text emerging through the application of practical stylistics are the following: (i) stylistic choices at word-level and at phrase-level (Quirk et al. 1985, 35-91); (ii) syntactic structures explored as meaning-making tools (ibid., 80153); (iii) the pragmatic functions and communicative effects of these choices and structures (Culpeper and Haugh 2014).

Given the ideological world Clarke belongs to, his imperial standpoint on India and Indian colonial railways is not at all surprising or unexpected. As a matter of fact, one of the key functions of stylistics is to test and confirm existing hypotheses (in this case, those elaborated by literary and cultural studies): close stylistic scrutiny enforces these hypotheses by laying bare the mechanisms of ideology construction (for the contribution of stylistics to evaluating textual worldviews and ideologies, see Simpson 1993; Jeffries 2010a; Jeffries 2010b; for the relationship of stylistics to critical discourse analysis, see the two books by Jeffries).

In order to achieve the research purpose of this article, Section 3 introduces the historical and literary figure of Hyde Clarke and his railway treatise, and Section 4 provides a discussion of the keywords colonialism and 
colonization as defined in two influential nineteenth-century dictionaries of the English language (Webster 1828; Murray 1893) and in colonial and postcolonial studies (Loomba [1998] 2015). In Section 5 I investigate the notion of colonization as emerging from thirteen sequences from Clarke's pamphlet including this keyword. I have preferred colonization to other possible options given that, in Clarke's text, the main function of the train is conceived of as providing the British with military defence in their Indian empire, consequently as contributing to their political and economic colonization of the subcontinent. Lastly, in Section 6 I compare the definitions of colonialism and colonization with Clarke's idea of colonization and present the conclusions of this stylistic and ideological study.

\section{Hyde Clarke and Colonization, Defence, and Railways IN OUR INDIAN EMPIRE (1857)}

Hyde Clarke was a man of broad interests who was engaged in a wide variety of activities: a considerable figure among British statisticians and engineers of his day, a financial journalist of long standing and a member of the British Association for the Advancement of Science (now British Science Association). His achievements ranged from founding the Railway Register and editing it in the years 1844-1847, to being the vice-president of the London (later the Royal) Statistical Society, the secretary of the Council of Foreign Bondholders, the influential treasurer for the Royal Society of Arts, and the now forgotten but prolific author of over forty books about statistics, philology and ethnology.

His diverse works were and still are quoted as authoritative in farapart, if not altogether different, books and articles about, for instance, Indian cotton and colonial railways (Grant 1850), Indian financial statistics (Hendriks 1858), Biblical philology (Beke 1871), Chinese Buddhist priests allegedly discovering America in the fifth century (Leland 1875), the use of drugs in relation to intellectual life (Reade 1883), British investments abroad (Cairncross 1935), British investments overseas (Platt 1980), his relations with the Russian economist N. D. Kondratieff (Black 1992), the instability of economic markets (Perelman 1999), comparative Creole literatures (Lang 2000), English, Indian and Australian exhibitions (Hoffenberg 2001).

More directly involved with colonial railways in nineteenth-century India, in writing about the relationship between trains and poverty in 
that country, Thorner $(1977,9,11)$ cites Clarke's works and notes: "Hyde Clarke, perhaps the most penetrating railway economist of the day, was more concerned with capitalizing on India's poverty than with analyzing it". Furthermore, he "cleverly argued with the East India Company in 1845 that it was no misplaced philanthropy which dictated the need for railways, but practical political wisdom. [...] Returning to the same subject a little later in 1845, Clarke summed up his views from a somewhat different angle, but in the most authentic early Victorian terms. Self-interest, he asserted, was the mainspring of all the things in the world".

It is on this Victorian ideology and utilitarian mindset that Clarke's treatise Colonization, Defence, and Railways in Our Indian Empire (1857) is based. This pamphlet was dedicated to the East India Company, the statelike entity responsible for governing the subcontinent between 1757 and 1858, and was published during the Indian Mutiny of 1857 against that Company. This revolt, which raged across much of the northern and central regions of the subcontinent, proved to be one of the most remarkable turning points in its history: it actually resulted in the East India Company breaking up in 1858 and in the subcontinent being governed directly from London. The British were subsequently compelled to reshape their colonial administration, financial system and army. It is thus no coincidence that, as mentioned above, in 1857 there were just 200 miles of rail line, whereas at the turn of the century they had increased to nearly 25,000 miles, and India's railway mileage had surpassed Britain's. In other words, it was after the Indian Mutiny that railway construction picked up pace, as a way to reinforce the colonisers' precarious grip on the colonised and to economise on military expenses.

As Srinivasan (2006, xvii) notes, "In keeping with the tradition of railway construction in India, each pressure group lobbied hard through the Press, via printed pamphlets, through the Chambers of Commerce and through contacts in the Government in India or with the Secretary of State in London, to ensure that it was their vision that would shape the Indian railscape". Clarke's treatise can easily be ascribed to this communication policy and tactics in canvassing ideas as persuasively as possible, along with seventeen newspaper articles about the Northern Bengal Railway Company; the author deliberately chose to include them in the "Appendix" to his pamphlet as "Extracts from the Press" (Clarke 1857, 224-44), and they are therefore an integral part of the treatise. Yet, it is his clear "vision" of "the Indian railscape" and his remarkable political and economic insight into the issue which make his treatise stand out against similar works. In fact, in his "Preface", Clarke (ibid., v) himself wrote 
that "The account here given of the hill stations is the first comprehensive statement of the progress and present condition of English colonization". In addition, Bear $(2007,26)$ points out that the pamphlet made "The first clear statement of the potential importance of railways to the security of populations in India" after the 1857 Mutiny. Military and strategic considerations of empire-building concerning the routing of the Indian railways inspired the treatise, which encouraged the construction of railways to the hill stations, or government settlements in the low mountains, of Simla in the northern part of the subcontinent and of Darjeeling in the north-east.

From Clarke's perspective, one of the main goals of railways would be to allow the country to be governed from those cities; a direct result of this would be the relocation to the hills of all the colonial administration and facilities (for the preference for the hill regions, see the analytical Section 5). Nevertheless, as Robinson argues (1991, 4), trains "opened new lands for settlement, attracted more immigrants from Europe, and accelerated colonization. They were used as agents of nation-building as well as empire-building”. Accordingly, among the sundry interrelated political, military, economic, financial, industrial, social, cultural and ecological transformations which railways could and did produce, in Clarke's view their main objective was certainly not to develop the domestic economy ${ }^{3}$. It was to allow British funds, middle class and working class to enter those regions; namely, to secure the reproduction of English population and capital, and to build and enlarge what Robinson himself terms the financial and commercial "informal empire" of the British in India (ibid., 4-5 $)^{4}$.

\footnotetext{
${ }^{3}$ See Sethia 1991, 103: "the impact of such a vast railway enterprise on the industrialization and economic growth of the Indian subcontinent was rather insignificant compared to other nations where the railroad revolution was central to the modernization and development process. [...] The process of imperial control over railway construction and operation frustrated industrial development and led to uneven economic growth of the Indian subcontinent”.

${ }^{4}$ However, Misa (2004, 98-99), who defines British technologies in the years 18401914, comprising Indian colonial railways, as the "instruments of Empire", observes that "The tremendous cost of these military campaigns [e.g., the Indian Mutiny] as well as the ongoing expenses for transporting, lodging, provisioning, and pensioning imperial officials simply ate up the profits of empire". Hence, railway imperialism in the subcontinent "did not generate wealth. Rather it shifted wealth from taxpayers in India and Britain to wealthy traders, investors, military officers, and imperial officials, who became its principal beneficiaries”.
} 


\section{THE TERMS COLONIALISM AND COLONIZATION}

This section explores colonialism and colonization, the terms under investigation in this article, from two different but interacting perspectives. In order to avoid the danger of anachronistic interpretation, the first perspective is supplied by two influential nineteenth-century dictionaries of the English language. Webster's An American Dictionary of the English Language was first published in 1828; its second edition, the last made by its author before his death, appeared in 1841. Volume II of Murray's A New English Dictionary on Historical Principles, covering words starting with the letter C, was published in 1893; this dictionary will evolve into the first edition of the Oxford English Dictionary, whose last fascicle was printed in 1928. Since these dictionaries provided general reference for the contemporary reading public, they now suggest how colonialism and colonization were perceived by that public, along with the reality the two terms represented and the ideology they reflected.

The second perspective on the two terms scrutinised here is furnished by colonial and postcolonial studies (see basic references in Section 2). Both Trevelyan's and Nehru's ideological positions as quoted in the introductory Section 1 are clearly recalled by the definitions of colonialism and colonization provided, among others, by Loomba ([1998] 2015). I have chosen to refer essentially to this book for the definitions of these terms for at least two reasons: (i) it is an authoritative introduction to the field now in its third edition; (ii) the definitions it offers are polyphonic and combine voices and stances from other texts and scholars, as shown below.

\subsection{Colonialism}

While there is no entry for the term colonialism in the first two editions of Webster's Dictionary (1828 and 1841), the New English Dictionary (Murray 1893) defines it as follows:

1. a. The practice or manner of things colonial.

1. b. A practice or idiom peculiar to or characteristic of a colony. (Cf. provincialism)

2. The colonial system or principle. (Murray 1893, 634)

With a view to understanding what "things colonial" and "The colonial system or principle" denote, hence what colonialism denotes, it is necessary to look up the sense of colony (the root of colonial) most relevant to this article: 
II. 4. A settlement in a new country; a body of people who settle in a new locality, forming a community subject to or connected with their parent state; the community so formed, consisting of the original settlers and their descendants and successors, as long as the connexion with the parent state is kept up. (Murray 1893, 634)

In Loomba's book about colonialism and postcolonialism ([1998] 2015), several pages are devoted to defining the term colonialism. This author starts by commenting on the sense of colony from the New English Dictionary quoted above, which can be found verbatim in the Oxford English Dictionary today (19-20): she criticises it for mentioning the colonisers only and failing to mention the colonised who might have been dwelling in the colonised areas. She then arrives at this working definition: "colonialism can be defined as the conquest and control of other people's lands and goods" (20), and eventually elaborates it as follows:

Modern colonialism did more than extract tribute, goods and wealth from the countries that it conquered - it restructured the economies of the latter, drawing them into a complex relationship with their own, so that there was a flow of human and natural resources between colonised and colonial countries. (Loomba [1998] 2015, 21; see also 22-24)

Loomba adds that this colonial flow of resources moved in both directions, yet its profits invariably moved towards, in the New English Dictionary's words, "the parent state" only (21). This is what Clarke openly wishes for and plans out in his pamphlet, as proven in the examination in Section 5.

\subsection{Colonization}

In the first two editions of Webster's Dictionary (1828 and 1841), the term colonization, one of the keywords in Clarke's text, is delineated in an essential way: "The act of colonizing, or state of being colonized". The same term in the New English Dictionary (Murray 1893, 634) is defined in equally essential words: "The action of colonizing or fact of being colonized; establishment of a colony or colonies". Further information is therefore required, namely the meaning of the root colonize. Its meaning is the same in both Webster's Dictionary and the New English Dictionary, but the former provides a longer and more informative description of the process: 
1. To plant or establish a colony in; to plant or settle a number of the subjects of a kingdom or state in a remote country, for the purpose of cultivation, commerce or defense, and for permanent residence.

2. To migrate and settle in, as inhabitants. (Webster 1828, n.p.)

What makes this definition more detailed than the one in the New English Dictionary is the fact that it lists four diverse but connected thrusts of colonization, i.e. "cultivation, commerce or defense, and [...] permanent residence", all of which are discussed in Clarke's treatise and in the sequences explored here. Loomba's criticism of the New and Oxford English Dictionary sense of colonialism partly applies to both senses of colonize in Webster's Dictionary. On the one hand, the noun phrases "cultivation, commerce" and "permanent residence" do not relay the idea of an encounter with the inhabitants of the colonised areas. On the other hand, the noun "defense" entails guarding from adversaries and alludes to the conquest and domination of those inhabitants and areas.

This meaning is expanded and made more explicit by Loomba ([1998] 2015, 27). She briefly defines colonization as "the takeover of territory, appropriation of material resources, exploitation of labour and interference with political and cultural structures of another territory or nation". She then amplifies her definition:

Many nineteenth- and twentieth-century writers equated the advance of European colonisation with the triumph of science and reason over the forces of superstition, and indeed many colonised peoples took the same view. (40-41)

Lastly, this author cites the work of the Marxist scholar Aimé Césaire (19132008) to round off her definition:

Césaire writes the colonial encounter as an equation: "colonisation = thingification" $(1972,21)$. This "thingification", or the reduction of the colonised person into an object, was achieved not only by turning her/him into "an instrument of production”, but also, by Western accounts [...] of subject-formation. (138-39)

Césaire's "subject-formation" was also accomplished by means of Loomba's "triumph of science and reason", namely of European knowledge, education and technology in the colonised areas; in the colonial ideology, this was overtly related to the economic development of those areas and to the exploitation of labour, capital and resources, and was reckoned to be progress (41).

What use does Clarke make of these keywords in his treatise? In the entire text of Colonization, Defence, and Railways in Our Indian Empire, there are no occurrences of the value-laden keyword colonialism. Instead, the 
equally value-laden keyword colonization occurs 27 times. To be more exact, it is present once both on the title page and in the dedication, twice in the preface, three times in the table of contents, four times in the chapter headings, once in the appendix with the newspaper articles and the remaining fifteen times in the main text. The instances of colonization with a longer and broader co-text are the fifteen in the main text and the one in the appendix; these sixteen instances occur in thirteen different sequences (see Appendix to this article). Consequently, in the following Sections 5 and 6, these instances of colonization and their co-texts are used to infer Clarke's definition of the keyword and to contrast it with those from the dictionaries and with Loomba's, hence to discover the main purposes of railways in the subcontinent after the Indian Mutiny according to the author of the text.

\section{PRACTICAL STYLISTIC ANALYSIS}

The thirteen sequences concerning the colonization of the Indian subcontinent abound in words, phrases and clauses relaying both the positive representation of a progressive ideology and the sharp reality of aggressively colonial - that is to say, political, military and economic - occupation. For instance, the noun phrase "some of the greatest measures which can be proposed for the benefit of India" (Clarke 1857, 8) apparently refers to the subcontinent and to the advantage gained by its inhabitants through colonization, but the noun "India" actually alludes to "British India" only or, rather, to the British occupying the subcontinent only. This is confirmed immediately afterwards by one of those "greatest measures" being openly glossed as "The control of India by English troops" (see also "the defence of India, the maintenance of a stable government" (123), where "India" implicates "British India", and "a stable government" "a stable British government").

As can be understood by reading the sequences, the nationality adjective "English" is prominently employed, and it performs the syntactic function of premodifying the nominal heads which denote the main figures and pursuits in the process of colonization through the railway. In Clarke's view, this process would allow the "English" (126-27), "the English race" (3) and "an English population" (8, 126-27) to safely occupy that region and establish British culture and society there. The railway would permit the promotion of English migration (8) or, more precisely, 
[...] all that is now required to promote a complete European colonization of the hill regions is $[\ldots]$ to organize an Emigration and Land Sales Department under a Commissioner or Commissioners. (91)

An immigration of 50,000 men, women, and children per year would be within the limits of the ultimate progress, and such numbers would constitute an effective and powerful colonization. (124-25)

The colonization of the hill regions of India with English will give us a hold which can never be shaken off. (126)

An English population of one million will render revolt or revolution in India impossible, and secure its peaceable settlement and our perpetual domination; (126-27)

These statements and exact data indicate that the author considers British occupation not only as military, political and economic colonization; ultimately and crucially, he also considers it as civil colonization, consequently as persistent and designed to continue indefinitely without change.

The resulting setting up of "English enterprise" (89) would allow "English pay in English health and efficiency" (126-27). The noun phrase "English enterprise", in its co-text, hints at "the introduction of tea culture into India" (89). It hence underlines the fact that not only would the activities undertaken by the British in the subcontinent have an economic and commercial end, but they would also regard consumer products suiting British needs and tastes, and not those expanding or improving Indian businesses or markets. This Anglocentric viewpoint and this Anglocentric value system are reinforced by the string "English pay in English health and efficiency". Foregrounded by the repetition of the nationality adjective, it signals directly that the economic, hygienic and service standards of colonization would be British, thereby indirectly suggesting that those distinctive of the subcontinent are poor and inadequate.

The author does not fail to mention that "English troops" (8) would keep this cultural and social order, and would control India. The sequences in fact abound in nouns and lists of nouns which denote soldiers and armed forces: "force", "recruits", "army", "barracks", "militia", "pensioners", "reserve", "cantonment", "troops", "veterans", "volunteers", even "invalids". The lexical "occupation" of the text by several nouns referring to various categories of soldiers reflects the military occupation of the subcontinent by the British, and gives prominence to the fact that it is their military colonization which allows, paves the way for and maintains socioeconomic and cultural colonization.

Notably, the nationality adjective "English" occurs in the sequences along with "European", so that, among other instances, reference is made 
to "thorough European administration" (8), "European traffic, colonization, and enterprise" (10), "a complete European colonization of the hill regions" (91). Nevertheless, when the various co-texts and contexts of the adjective "European" are taken into consideration, and when the socioeconomic and political background of the mid-nineteenth century is also borne in mind, the adjective seems to be used more as a synonym of "English" for reasons of stylistic elegant variation, and as an antonym of "Asian", "Indian", "native", than to trigger any special implicature, or additional conveyed meaning (Grice 1975).

Clarke consistently states that European colonization should particularly concern the hill regions of the Sub-Himalayas and Neilgherries (1857, 10, 87-88, 91, 126-27), namely, the areas of "Simla, Darjeeling, Ootacamund, Landour, Soobathoo, \&c." (131). His pamphlet highlights the substantial economic costs of the process of colonization in those regions. It therefore includes explicit hints at "the large contribution required for immigration" (123), and also submits his views and plans as if they were positive facts:

A guarantee of five per cent., or $£ 100,000$ a year, will place these undertakings in activity, and effect some of the greatest measures which can be proposed for the benefit of India, (8)

In order to effect the English colonization of India on a large scale, large funds must be provided, and those cannot be afforded out of the present revenues of India. (123)

Given the communicative function or illocutionary force of the message conveyed throughout the entire treatise, and Clarke's intention or perlocutionary force in emitting that message (Searle 1969; Austin [1962] 1975), frankly alluding to the expenses of British occupation appears to be one of the author's tactics to persuade his target audience by representing himself as open, sincere and trustworthy, and by depicting that occupation as already planned out in a logical way, consequently as unquestionably successful and profitable.

The choice of the hill regions actually has strategic and utilitarian causes. Firstly, they have been selected by Clarke because of their "climates suitable for the English race" $(1857,3)$, "European climate" (10, 87-88), "healthy climate" (126-27). Secondly, and more importantly, those areas are, in Clarke's words, "now comparatively unproductive of revenue" (87-88). Hence, the economic and material benefits of the colonization process would be similarly "large" and means-tested, benefits which the author repeatedly alludes to even more directly and enthusiastically: 
The establishment of a large land revenue available for internal improvements, for promoting immigration, and for redeeming the national debt. (8)

The cantonment of a large European force in a European climate on European pay. (88)

In those settlements will be maintained a larger European force than is now kept up, (126)

Therefore, as emerges from these citations, British occupation is portrayed as undoubtedly profitable, from many diverse standpoints, but first and foremost for the occupiers. This is implicitly confirmed by the following quotation:

Those revenues [the present revenues of India] have to meet charges connected with the defence of India, the maintenance of a stable government, and the advancement of native interests and native progress; and they are, therefore, in no condition to afford the large contribution required for immigration. (123)

Indian revenues are here assumed to be separate from the revenues deriving from colonization and from the railway. At a first reading, this seems fair to the "natives", for it suggests that subcontinental incomes would only be utilised and invested for their sake. However, the other side of the argument is that it also presupposes that colonization and railway revenues would be used exclusively to promote British economic interests and enhance their occupation of India.

Another main explanation for Clarke's preference for the hill regions is similarly strategic and utilitarian: administrating the military occupation of the entire subcontinent from those safe areas. In Sequence 3, he writes that the train in the hill regions would "provide for the military organization" (10), a consideration developed and elaborated in the entire Sequence 10 (126-27). The sequence is especially rich in ideological, positively value-laden and even hyperbolic words, phrases and clauses underscoring the advantages of managing military colonization from the hills, and ranging over the wide variety of its features. Those which are given more ideological prominence are the persistence in time of that occupation ("a hold which can never be shaken off", "keep India under ultimate control", "our perpetual domination"; emphasis added), and the success and effectiveness of the colonization process. This is the case both within the subcontinent's borders ("render revolt or revolution in India impossible") and outside them ("render its frontiers on the north and northwest unassailable", "all prospects of a Russian invasion will be at an end").

Several of the sequences which include the keyword "colonization" also comprise the culturally positively value-laden noun "progress", in both its denotations of "forward movement in space" and "advancement, especially to 
a better state or condition". As a result, "The progress of trunk railways" (87), which directly causes "the progress of English colonization in India under the auspices of the Indian Government" (89), also gives grounds for "the advancement of native interests and native progress" (123) just mentioned. The text thus communicates that the action of the colonial train journeying or moving onward is directly related to socioeconomic growth and cultural development, i.e., to what colonialism is in Clarke's ideology. More precisely, it is colonialism which sparks off progress at the diverse levels mentioned above.

In the author's worldview of the British role in India, religious progress is included in the idea of colonization and advancement. Along with sundry facilities typified as European (for example, the "branch roads, [...] town sites, [...] barracks" (10) cited in the title of this article), a number of the sequences quote the introduction of churches and chapels into the subcontinent in praising terms. To be more exact, on the one hand, that British infrastructure is commonly presented and catalogued through lists, such as "barracks, hotels, schools, churches, and public edifices" (10), and "detached villas, churches, schools, libraries, invalid barracks, orphan institutions, and other English establishments" (227). As Hillier notes (2004, 124-25), the syntactic pattern of the list, whose pragmatic function is to "do ideological 'work' on audiences", is prototypically composed of a series of three specific components, and is accordingly defined as three-part list.

Nevertheless, the lists in Clarke's text usually consist of more than three components, those just mentioned being constituted by five and seven items, respectively. The higher the number of components, the more ideological work they do; hence, not only do Clarke's lists extol British achievements in India, but they also portray them as numberless. In addition, the items comprised in them range over a wide variety of facilities, namely from private to military buildings, from educational to tourist structures ("the great railway repairing establishments, on the scale of Wolverton, Swindon, and Crewe" (1857, 136-37), although not included in a list, should not be overlooked). Hence, they implicitly describe the subcontinent, before British colonization, as lacking all essential facilities to its socioeconomic life and cultural development. For these reasons, the author's lists can easily be categorised as another of those stylistic features which turn his treatise into a persuasive text.

Apart from their being recurring items in lists, the role and relevance of churches and chapels are emphasised through this noun phrase: "churches and chapels, which are the real, vital, and stable seats of religion in India" (131). The phrase is foregrounded by at least two stylistic means: (i) the pho- 
netic and graphological alliteration of the voiceless postalveolar affricate [t $\mathrm{f}]$; (ii) the three-part list of adjectives "real, vital, and stable". The alliteration is more salient as it occurs on two word-initial syllables and on the two coordinated nominal heads of the phrase. The list expresses the positively valueladen characteristics of what is assumed to be the actual religious authority in the subcontinent, viz., the Church of England. No direct mention is made to any of the world's four major religious traditions originated in India hundreds, if not thousands, of years before Christianity, that is to say, Hinduism, Buddhism, Jainism and Sikhism. In pragmatic terms, such Gricean Quantity zero (Grice 1975) implicates that, in Clarke's biased mindset, none of those traditions is of any importance or interest whatsoever. Moreover, the "fact" that the religion of the Church of England is allegedly free from nonsense, full of energy, firmly established, as evoked in the list, triggers the implicature that all the various religions practised in India are not characterised by those positive aspects or, rather, they are not characterised by any positive aspects at all. The broader implicature which arises from these specific co-text and context is that it is the entire subcontinent, with its culture and society, which is typified by a total lack of pleasant traits, therefore that its colonization by the British is not only justifiable but also beneficial for the Indians themselves.

Although readiness to prevent and combat potential future threats of the Indian Mutiny-type is one of the main reasons for the amplification of the railway in the subcontinent, the sequences only mention the Indian Mutiny through one indirect referring expression: "the experience of late events" (Clarke 1857, 8). A gentle hint is also given about rebellions to come, such as "any great crisis" (87-88) and "revolt or revolution in India" (126-27). Not openly alluding to an entity or notion is one of those stylistic devices deployed by the colonisers to confuse ideology with reality or, rather, to represent ideology as reality.

What results from this practical stylistic analysis of the thirteen sequences and from the examination of the key linguistic tools Clarke utilised in them? The study of his stylistic selections at word-level and at phrase-level, of meaning relayed by syntactic choices, and of the pragmatic functions of these selections and choices has proven that he does not devote the sequences to defining and describing the reasons for colonization; on the contrary, they are dedicated to what, in his opinion, would be its favourable effects on both the British and the Indians. Unsurprisingly, the effects which the author denotes and connotes as benign are the very same which Loomba, in her book considered above, regards as negative for the Indians. 


\section{CONCLUSIONS}

This practical stylistic analysis of the thirteen sequences from Clarke's treatise has shown that underlying the sequences are several features of the processes of colonialism and colonization identified in Webster's Dictionary and in Murray's New English Dictionary and discussed by Loomba in her definitions of the two terms from the perspective of colonial and postcolonial studies. The "settlement in a new country" (Murray), "plant[ing] or establish[ing] a colony" (Webster) and "the takeover of territory, appropriation of material resources, exploitation of labour" (Loomba) are nearly taken for granted in Clarke's sequences about the British colonization of India. In the sequences, the British have already settled in the subcontinent, it has already been dominated, its available assets taken possession of, its workforce capitalised on; such civil, military, commercial and economic domination only needs consolidating and expanding. Regarding "the purpose of cultivation, commerce or defense" (Webster) and "interference with political and cultural structures" (Loomba), British commercial and political authority is also a given, whereas cultural and especially religious influence is depicted as necessary and certain to happen; however, it is mostly reserved for the British and not for the Indians, who are implicitly portrayed as unworthy of the "successful" outcomes of foreign occupation. For these reasons, Clarke is one of those nineteenth- and twentieth-century authors who, as Loomba herself points out, reckon the colonised to be incompetent, irrational and credulous, and the colonisers to be the bearers of progress, knowledge and prosperity, as symbolised, in the sequences, by the railway. Concerning Césaire's idea of thingification and objectification of the colonised (explored in Loomba), it does not appear to be fully applicable to the sequences. They deal mainly with British issues, requirements and arrangements, and not with the Indians, who are virtually absent from those sequences, and whose needs are hardly ever alluded to and never taken into account: this is fully in line with the definitions in the two dictionaries and with Loomba's criticism of the one in the New and Oxford English Dictionary.

In Clarke's Colonization, Defence, and Railways in Our Indian Empire, the reader can therefore find positions merging ideological stances similar to those Trevelyan and Nehru will adopt in the years to come, that is to say the romantic representation of Indian railways versus the economically convenient representation of the same railways. This author actually deploys a number of stylistic strategies to convince his target readers, namely the pro- 
spective financial backers of his project, that all the various British interests in the subcontinent after the Indian Mutiny could only be preserved and developed through the colonial railway. Hence, he also employs those persuasive stylistic devices to represent that project as an amazingly admirable and efficient enterprise with equally amazing income and material benefits. Nehru's critical, utilitarian, capitalist position as elaborated in the pamphlet, that is to say, a sharp representation of colonial reality in India, actually coincides with Trevelyan's approving, enthusiastic, romantic position, in other words, an ideological representation of the colonial reality in the subcontinent.

I would like to thank Prof. Jonathan H. Grossman and the anonymous reviewers of this article for their invaluable comments and advice on previous drafts of this work.

\section{REFERENCES}

Adami, Esterino. 2018. Railway Discourse: Linguistic and Stylistic Representations of the Train in the Anglophone World. Cambridge: Cambridge Scholars Publishing.

Adami, Esterino. 2019. "Living is Writing: Metaphors of Representation in Hanif Kureishi's The Last Word". Kervan: International Journal of Afro-Asiatic Studies 23 (special issue): 39-51.

Ashcroft, Bill, Gareth Griffiths, and Helen Tiffin. (1995) 2006. The Post-Colonial Studies Reader, 2nd edition. London: Routledge.

Ashcroft, Bill, Gareth Griffiths, and Helen Tiffin. (2000) 2007. Post-Colonial Studies: The Key Concepts, 2nd edition. London: Routledge.

Austin, John. (1962) 1975. How to Do Things with Words, 2nd edition. Oxford: Clarendon Press.

Bear, Laura. 2007. Lines of the Nation: Indian Railway Workers, Bureaucracy, and the Intimate Historical Self. New York: Columbia University Press.

Beke, Charles T. 1871. The Idol in Horeb: Evidence that the Golden Image at Mount Sinai was a Cone, and not a Calf: With Three Appendices. London: Tinsley Bros.

Bhabha, Homi K. (1994) 2004. The Location of Culture. London: Routledge (Routledge Classics).

Black, Collison. 1992. "Dr. Kondratieff and Mr. Hyde Clarke". Research in the History of Economic Thought and Methodology 9:35-58.

Burke, Michael (ed.). 2014. The Routledge Handbook of Stylistics. London: Routledge.

Linguce er-2/2020

https://www.ledonline.it/linguae/ - Online ISSN 1724-8698 - Print ISSN 2281-8952 - ISBN 978-88-7916-961-5 
Cairncross, Alexander K. 1935. "Did Foreign Investment Pay?". The Review of Economic Studies 3 (1): 67-78. https://doi.org/10.2307/2967573.

Carter, Ron. 2010. "Methodologies for Stylistic Analysis”. In Language and Style: In Honour of Mick Short. Ed. by Dan McIntyre and Beatrix Busse, 55-68. Basingstoke: Palgrave.

Césaire, Aimé. 1972. Discourse on Colonialism. New York: Monthly Review Press.

Clarke, Hyde. 1857. Colonization, Defence, and Railways in Our Indian Empire. London: John Weale. Reprint 2009, unknown location: General Books LLC.

Culpeper, Jonathan, and Michael Haugh. 2014. Pragmatics and the English Language. Basingstoke: Palgrave.

Fanon, Frantz. (1952) 2008. Black Skin, White Masks. Translated by Richard Philcox. New York: Grove Press.

Grant, Charles W. 1850. Bombay Cotton and Indian Railways. London: Longman, Brown, Green and Longman.

Greenberger, Allen J. 1969. The British Image of India: A Study in Literature of Imperialism, 1880-1960. Oxford: Oxford University Press.

Grice, Herbert P. 1975. "Logic and Conversation”. In Syntax and Semantics: Speech Acts, Volume 3. Ed. by Peter Cole and Jerry L. Morgan, 41-58. New York: Academic Press.

Hendriks, Frederick. 1858. "On the Statistics of Indian Revenue and Taxation”. Journal of the Statistical Society of London 21 (3): 223-96. https://doi.org/10.2307/2338224.

Hillier, Hilary. 2004. Analysing Real Texts: Research Studies in Modern English Language. Basingstoke: Palgrave.

Hoffenberg, Peter H. 2001. An Empire on Display: English, Indian, and Australian Exhibitions from the Crystal Palace to the Great War. Berkeley: University of California Press.

Iqbal, Iftekhar. 2006. "The Railway in Colonial India: Between Ideas and Impacts”. In Our Indian Railway: Themes in India's Railway History. Ed. by Roopa Srinivasan, Manish Tiwari, and Sandeep Silas, 173-86. New Delhi: Foundation Books.

Jeffries, Lesley. 2010a. Critical Stylistics. Basingstoke: Palgrave.

Jeffries, Lesley. 2010b. Opposition in Discourse. London: Continuum.

Johnson, Alan. 2000. "Club Members? Reading John Masters's Bhowani Junction". The Journal of Commonwealth Literature 35 (1): 3-26.

https://doi.org/10.1177/0021989004230813.

Kerr, Ian J. 2001. "Introduction”. In Railways in Modern India. Ed. by Ian J. Kerr, 1-61. New Delhi: Oxford University Press India. 
Lang, George. 2000. Entwisted Tongues: Comparative Creole Literatures. Amsterdam: Rodopi.

Leech, Geoffrey, and Mick Short. (1981) 2007. Style in Fiction: A Linguistic Introduction to English Fictional Prose, 2nd edition. London: Longman.

Leland, Charles G. 1875. Fusang, or, The Discovery of America by Chinese Buddhist Priests in the Fifth Century. London: Trübner.

Loomba, Ania. (1998) 2015. Colonialism/Postcolonialism, 3rd edition. London: Routledge.

Misa, Thomas J. 2004. Leonardo to the Internet: Technology and Culture from the Renaissance to the Present. Baltimore: Johns Hopkins University Press.

Murray, James A. H. (ed.). 1893. A New English Dictionary on Historical Principles: Volume II: C. Oxford: Clarendon Press.

Nehru, Jawaharlal. 1982. An Autobiography. New Delhi: Jawarharlal Nehru Memorial Fund; Oxford: Oxford University Press.

Perelman, Michael. 1999. The Natural Instability of Markets: Expectations, Increasing Returns, and the Collapse of Capitalism. New York: St. Martin's Press.

Platt, Desmond C. M. 1980. "British Portfolio Investment Overseas before 1870: Some Doubts”. The Economic History Review, New Series 33 (1): 1-16. https://doi.org/10.2307/2595540.

Quirk, Randolph, Sidney Greenbaum, Geoffrey Leech, and Jan Svartvik. 1985. A Comprehensive Grammar of the English Language. London: Longman.

Reade, Alfred A. 1883. Study and Stimulants or, The Use of Intoxicants and Narcotics in Relation to Intellectual Life, as Illustrated by Personal Communications on the Subject from Men of Letters and of Science. Manchester: A. Heywood \& Son.

Robinson, Ronald E. 1991. "Introduction: Railway Imperialism". In Railway Imperialism. Ed. by Clarence B. Davis and Kenneth E. Wilburn Jr., 1-6. New York: Greenwood.

Searle, John R. 1969. Speech Acts: An Essay in the Philosophy of Language. Cambridge: Cambridge University Press.

Sethia, Tara. 1991. "Railways, Raj, and the Indian States: Policy of Collaboration and Coercion in Hyderabad". In Railway Imperialism. Ed. by Clarence B. Davis and Kenneth E. Wilburn Jr., 103-20. New York: Greenwood.

Simpson, Paul. 1993. Language, Ideology and Point of View. London: Routledge.

Simpson, Paul. (2004) 2014. Stylistics: A Resource Book for Students, 2nd edition. London: Routledge.

Smith, Tony. 1981. The Pattern of Imperialism: The United States, Great Britain, and the Late-Industrializing World since 1815. Cambridge: Cambridge University Press.

Linguce \& $-2 / 2020$

https://www.ledonline.it/linguae/ - Online ISSN 1724-8698 - Print ISSN 2281-8952 - ISBN 978-88-7916-961-5 
Sotirova, Violeta (ed.). 2015. The Bloomsbury Companion to Stylistics. London: Bloomsbury.

Srinivasan, Roopa. 2006. "Introduction". In Our Indian Railway: Themes in India's Railway History. Ed. by Roopa Srinivasan, Manish Tiwari, and Sandeep Silas, xiii-xxxiv. New Delhi: Foundation Books.

Stockwell, Peter, and Sara Whiteley (eds.). 2014. The Cambridge Handbook of Stylistics. Cambridge: Cambridge University Press.

Thorner, Daniel. 1977. Investment in Empire: British Railway and Steam Shipping Enterprise in India, 1825-1849. New York: Arno,

Trevelyan, George O. 1864. The Competition Wallah. London: Macmillan.

Trevelyan, George O. 1998. "An Indian Railway". In Empire Writing: An Anthology of Colonial Literature, 1870-1918. Ed. by Elleke Boehmer, 3-8. Oxford: Oxford University Press.

Tunca, Daria. 2014. Stylistic Approaches to Nigerian Fiction. Basingstoke: Palgrave.

Tunca, Daria. 2020. “'Nobody disappears. People don't just disappear': Repetition and Negation as Dialogic Devices in Caryl Phillips's 'Northern Lights'”. Journal of Literary Semantics 49 (1): 1-25. https://doi.org/10.1515/jls-2020-2018.

Virdis, Daniela F. 2012. “Ideological Landscapes in G. O. Trevelyan's 'An Indian Railway': An Ecostylistic Analysis". In Ekologiya yazyka na perekrestke nauk: materialy 2-y mezhdunarodnoy nauchnoy konferentsii: v 2-h chastyab: Ch. 1 (Ecology of Language at the Crossroads of Sciences: Proceedings of the $2^{\text {nd }}$ International Scientific Conference in 2 Volumes: Volume 1). Ed. by N. N. Belozerova, 40-47. Tyumen (Russia): Izdatelstvo Tyumenskogo gosudarstvennogo universiteta (Tyumen State University Publishing House).

Webster, Noah. 1828. An American Dictionary of the English Language. New York: S. Converse.

Webster, Noah. 1841. An American Dictionary of the English Language, 2nd edition. Amherst, MA: J. S. \& C. Adams Brothers.

Young, Robert J. C. (2001) 2016. Postcolonialism: An Historical Introduction: Anniversary Edition. Oxford: Wiley-Blackwell.

Zurru, Elisabetta. 2017. "The Agency of The Hungry Tide: An Ecostylistic Analysis". In The Stylistics of Landscapes, the Landscapes of Stylistics. Ed. by John Douthwaite, Daniela F. Virdis, and Elisabetta Zurru, 191-231. Amsterdam - Philadelphia: John Benjamins. 


\section{APPENDIX: THE THIRTEEN SEQUENCES}

1. [..] we may proceed to the proved and notorious fact, that there do exist in India countries and climates suitable for the English race, and that the seeds of such colonization have been sown. (Clarke, 1857, 2-3; emphasis added, here and below)

2. A guarantee of five per cent, or $£ 100,000$ a year, will place these undertakings in activity, and effect some of the greatest measures which can be proposed for the benefit of India, more particularly since the experience of late events. These measures include -

3. The government of India by thorough European administration;

4. The control of India by English troops;

5. The colonization of India with an English population;

6. The establishment of a large land revenue available for internal improvements, for promoting immigration, and for redeeming the national debt. (8)

7. The Simla and Hill Junction Railway Company will, in the cheapest form of railway construction, open out the hill regions to European traffic, colonization, and enterprise, and provide for the military organization. It will lay down branch roads, provide town sites, build barracks, hotels, schools, churches, and public edifices, and assist in the development of the countries of European climate. (10)

8. The progress of trunk railways under the auspices of the Honorable Court has, however, been attended with circumstances most auspicious for the extension of the sanitaria and hill colonization. (87)

9. The promoters of this undertaking consider that so far from being restricted to a communication with Simla, it is desirable it should be so constituted as to afford the means for establishing English colonization, not only at Simla or Soobathoo, but generally in the Sub-Himalayas and Neilgherries, by the promotion of railways, the erection of the necessary buildings and works, and the introduction of emigrants. [...] The great results of such operations would be:

1st. The English colonization of the hill regions, now comparatively unproductive of revenue.

2nd. The cantonment of a large European force in a European climate on European pay.

$3 \mathrm{rd}$. The constitution of a reserve of invalids, pensioners, recruits, and militia, available for any great crisis, beyond the regular army. (87-88)

10. Some notion will have been already formed of the progress of English colonization in India under the auspices of the Indian Government, and from the spread of English enterprise. [...] Singularly enough the introduction of tea culture into India has become an instrument of English colonization. (89)

11. $[\ldots]$ all that is now required to promote a complete European colonization of the hill regions is, as herein pointed out, to encourage and construct branch railways 
and tramways, and to organize an Emigration and Land Sales Department under a Commissioner or Commissioners. (91)

12. In order to effect the English colonization of India on a large scale, large funds must be provided, and those cannot be afforded out of the present revenues of India. Those revenues have to meet charges connected with the defence of India, the maintenance of a stable government, and the advancement of native interests and native progress; and they are, therefore, in no condition to afford the large contribution required for immigration. (123)

13. An immigration of 50,000 men, women, and children per year would be within the limits of the ultimate progress, and such numbers would constitute an effective and powerful colonization. (124-25)

14. The colonization of the hill regions of India with English will give us a hold which can never be shaken off. In those settlements will be maintained a larger European force than is now kept up, and it will be maintained at English pay in English health and efficiency. Residence in a healthy climate and a land bounty will never leave the Indian army without recruits or volunteers. The recruits, invalids, pensioners, and veterans of this active force will be kept in the hills, affording a copious reserve; and the colonization will afford a numerous militia, which will keep India under ultimate control, and render its frontiers on the north and north-west unassailable. An English population of one million will render revolt or revolution in India impossible, and secure its peaceable settlement and our perpetual domination; while all prospects of a Russian invasion will be at an end. (126-27)

15. At Simla, Darjeeling, Ootacamund, Landour, Soobathoo, \&c., are established churches and chapels, which are the real, vital, and stable seats of religion in India, and with the extension of colonization, it follows that a great supply of clergymen and churches will be attendant upon it. (131)

16. It is at Darjeeling and the hill towns that the great railway repairing establishments, on the scale of Wolverton, Swindon, and Crewe, will be ultimately placed [...]. These establishments will powerfully aid European colonization, and supply the railway with passenger traffic to and fro, and down goods traffic. (136-37)

17. These towns [...] are small towns with detached villas, churches, schools, libraries, invalid barracks, orphan institutions, and other English establishments, and are the elements of a European colonization of India. (227, Appendix) 